УДК 551.7:549:551.2.01(470.32)

DOI: https://doi.org/10.17308/geology.2020.1/2520

Поступила в редакцию: 12.02.2020

Принята к публикации: 20.02.2020

Опубликована онлайн: 25.03.2020

\title{
Выпускники-геологи Воронежского университета в Забайкалье
}

\author{
(C2020 О. Р. Минина ${ }^{\bowtie}$ \\ Геологический институт Сибирского отделения Российской академии наук, \\ ул. Сахьяновой, 6А, 670000, Улан-Удэ, Российская Федерация
}

\begin{abstract}
Аннотация
Республика Бурятия расположена в южной части Восточной Сибири, южнее и восточнее озера Байкал. Бурятия является субъектом Российской Федерации и в настоящее время входит в состав Дальневосточного федерального округа. По богатству и разнообразию ресурсного потенциала Бурятия лидирует среди большинства субъектов Российской Федерации. За последние полвека в республике выявлено более 700 различных по генезису месторождений полезных ископаемых, из них более 600 учтены государственным балансом России. Вся территория региона изучена кондиционной среднемасштабной геологической съемкой. В изучение геологического строения и развитие минерально-сырьевой базы республики большой вклад внесли выпускники геологического факультета Воронежского государственного университета.

Ключевые слова: ВГУ, Бурятия, выпускники, геологи.

Для цุитирования: Минина О. Р. Выпускники-геологи Воронежского университета в Забайкалье // Вестник Воронежского государственного университета. Серия: Геология. 2020. №1. С. 116-130. DOI: https://doi.org/10.17308/geology.2020.1/2520
\end{abstract}

В изучение геологического строения и развитие минерально-сырьевой базы республики Бурятия большой вклад внесли выпускники Геологического факультета Воронежского государственного университета. В разные годы в Бурятию по распределению приехали более 80 специалистов. Территориальное Бурятское геологическое управление (ТБГУ) было организовано в 1957 г. и остро нуждалось в геологах. В те годы главный геолог ТБГУ Б. М. Зубарев был членом Государственной экзаменационной комиссии на геологическом факультете университета и пригласил в республику молодых геологов. Самая большая группа выпускников геологов прибыла в Бурятию в период с 1958 до 1960 гг. Приезжали грамотные, наиболее подготовленные к самостоятельной работе выпускники. Молодые геологи сразу же вписывались в коллективы экспедиций, быстро набира-

\begin{abstract}
лись опыта и через несколько лет сами становились старшими геологами, начальниками партий и отрядов. Воронежцы проводили геологическую съёмку, поиски и разведку месторождений полезных ископаемых Бурятии, были авторами комплектов Геологических карт (ГГК-200) первого поколения и первооткрывателями месторождений. Многие из них, как высококлассные специалисты, были приглашены для участия в геологических работах за рубежами нашей Родины. И в последующие годы студенты геологического факультета приезжали на практику, а затем, уже молодыми специалистами, на работу в Бурятию. Многие из них оставались в этом суровом и необыкновенно красивом крае на всю жизнь, другие, начав свою геологическую карьеру в Бурятии, уезжали и достойно трудились и сейчас трудятся в других регионах России. Из выпускников геолфака ВГУ разных лет, прошедших
\end{abstract}

Контент доступен под лицензией Creative Commons Attribution 4.0 License.

\footnotetext{
$\bowtie$ Ольга Романовна Минина, E-mail: minina@ginst.ru
} 
школу геологической съемки и поисков, докторами геолого-минералогических наук стали Ф. Г. Рейф, Ю. П. Бутов, О. Р. Минина, степень кандидата геолого-минералогических наук получили Э. Н. Зеленый, Ю. И. Темников, Э. Л. Прудовский, Э. А. Максимова, В.И. Лосицкий.

Невозможно рассказать обо всех геологах-воронежцах, биографии и трудовой путь которых, связаны с Забайкальем и заслуживают уважения. Я расскажу только о некоторых из них.

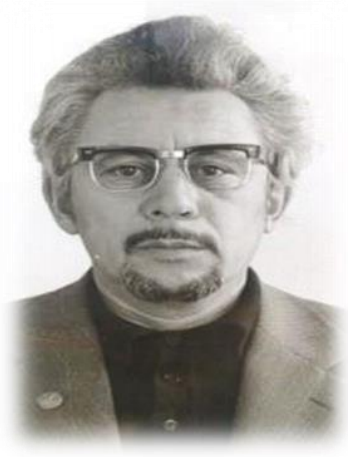

Темников Юрий Иванович
Одним из первых в Забайкалье после окончания Воронежского университета в 1956 г. прибыл Юрий Иванович Темников вместе с супругой Людмилой Григорьевной. Сначала он был направлен на работу в Читинскую область, где занимался поисками и разведкой месторождений редких элементов (бериллия, тантала, лития и др.). В 1963 г. Юрий Иванович перешел работать в Забайкальский НИИ МинГео СССР. В 1967

г. в институте Геологии и Геодезии Сибирского отделения АН СССР защитил диссертацию на соискание ученой степени кандидата геолого-минералогических наук, посвященную особенностям месторождений редких элементов, и был приглашен на работу в этот институт. По роду своей деятельности Ю. И. Темников работал во многих регионах Советского Союза (Казахстане и Узбекистане, Армении и на Дальнем Востоке до 1973 г.). В 1974 г. перешел на работу в Иркутский госуниверситет, где продолжил изучение редкометалльных месторождений. В Окинскую экспедицию он перешел на работу в 1978 г. и приступил к изучению Сорокского бериллового проявления. Позже Юрий Иванович проводил геологосъемочные и поисковые работы на территории Восточного Саяна и Хамар-Дабана, где возглавлял Утулинскую поисковосъемочную партию, занимался тематическими работами по магматизму Восточного Саяна. Ю. И. Темников автор более 60 опубликованных и рукописных работ, в том числе двух монографий. С 1988 г. живет в г. Воронеже. Я хорошо помню первую встречу с Юрием Ивановичем. Тогда в 1978 г. я, студентка Геологического факультета ВГУ, была направлена на производственную практику в Утуликскую партию. Мы встретились с Юрием Ивановичем на вертолетной площадке, перед заброской на площадь работ. Увидев меня, девчонку, да еще мелкую, он был очень раздосадован, сказал: «ее мне только не хватает, нечего тебе там делать и т.д.». Я, конечно же, всплакнула: «ну возьмите, я оправдаю....». На что Юрий Иванович ответил, что: «терпеть не может хныканий, ладно прыгай в вертолет, но смотри у меня.....»- так и начался мой первый, самый интересный полевой се- зон. В то время 10 студентов из разных городов СССР (Вильнюс, Иркутск, Новосибирск, Львов, Воронеж) проходили практику в этой партии. Судьба свела меня с замечательными людьми - геологами и студентами, тогда я и поняла, что не ошиблась в выборе профессии.

В 1958 году на работу в БГУ прибыли молодые инженеры-геологи Зеленый Эдуард Николаевич, Зеленский Евгений Емельянович, супруги Яновы Юрий Миронович и Мария Федоровна.

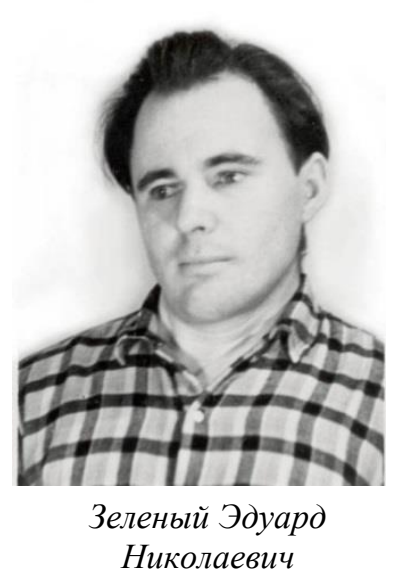

Зеленый Эдуард Николаевич был направлен на работу в Геологосъемочную экспедицию (позже переименованную в Центральную геологическую экспедицию), которая базировалась в г. Улан-Удэ и работала по всей территории Бурятии. В экспедиции он проработал 20 лет и прошел путь от старшего техника до начальника партии. Вся его жизнь и трудовая деятельность связаны с изучением геологии и полезных ископаемых Бурятии. Еще молодым специалистом Эдуард Николаевич участвовал в проведении геологических съемок масштабов 1:200 000 и 1:50 000, поисковых и оценочных работах. Он автор и соавтор 13 комплектов Государственных геологических карт. При его участии выявлены и изучены Ауникское редкометалльное, Ульзутуйское полиметаллическое, Оланское вольфрамит-шеелитовое месторождения. В период с 1978 по 1987 гг. Э. Н. Зеленый работал главным геологом Удино-Витимской экспедиции. В это время под его руководством проводится глубинное геологическое картирование Озернинского рудного узла, разведка Эгитинского флюоритового месторождения, запасы по которому защищены им с высокой оценкой в ГКЗ СССР. В этот период Эдуард Николаевич защитил кандидатскую диссертацию. С 1988 г. Э.Н. Зеленый был назначен главным геологом Селенгинской партии и занимался изучением Ошурковского аппатитового и Холинского перлитового месторождений, запасы по которым также успешно были защищены в ГКЗ СССР. С 1992 г. Э. Н. Зеленый в должности главного геолога продолжил свой трудовой путь в старательской артели «Курба». Здесь он руководил разведкой россыпей золота в Хоринском и Прибайкальском районах, добычей золота в новом, выявленном при его непосредственном участии, Еравнинском районе, где стал первооткрывателем крупного золотороссыпного месторождения. В настоящее время Эдуард Николаевич, закончив свою трудовую деятельность, остается активным, веселым и жизнерадостным человеком. За вклад в развитие минерально-сырьевой базы республики Бурятия Э.Н. Зеленый удостоен званий «Заслуженный геолог Бурятии», «Почетный разведчик недр», награжден орденом Знак Почета. 


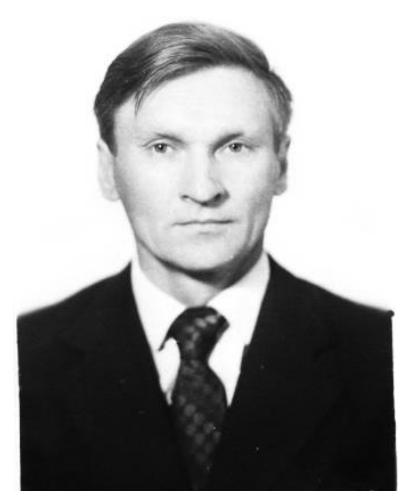

Зеленский Евгений Емельянович
Зеленский Евгений Емельянович, попав в Геологосъемочную экспедицию, проработал в ее составе до ухода на заслуженный отдых. Он практически с первых лет своей работы был бессменным начальником геологических партий, занимавшихся изучением геологического строения и полезных ископаемых Муйского, Баунтовского, Курбино-Еравнинского и Джидинского рудных районов. Евгений Емельянович первый автор четырех комплектов Геологических карт -200 первого поколения и двух Опорных легенд к ним, а также более 20 отчетов по геологическим и поисковым работам на уран, золото, цветные и редкие металлы. Особенно большой вклад Е. Е. Зеленский внес в изучение Джидинского рудного района и зоны БАМ. Опытный съемщик Е. Е. Зеленский возглавил в 80-е годы Дабанскую партию, изучавшую проявления рудного и россыпного золота Закаменского рудного поля, активно внедряя в геологическую практику геохимические методы поисков. Евгений Емельянович Зеленский - высочайший профессионал, эрудированный человек, с прекрасным чувством юмора, исключительно доброжелательный к окружающим его людям, внимательный и терпеливый наставник молодых геологов. Удостоен звания «Заслуженный геолог Республики Бурятия». Сейчас он находится на заслуженном отдыхе и уехал из Бурятии.

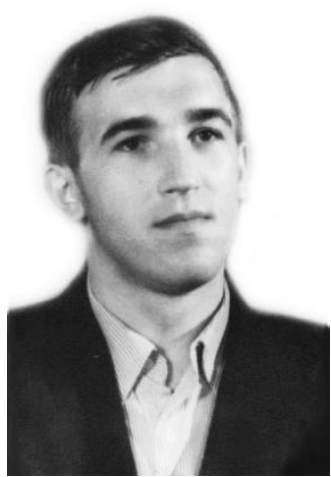

Янов Юрий Миронович

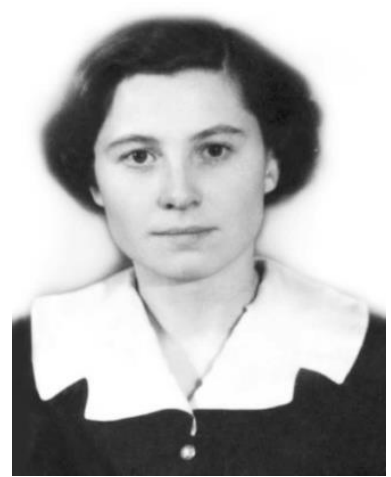

Янова Мария Федоровна
Супруги Яновы вместе со своими сокурсниками при распределении выбрали Бурятию и Геологосъемочную экспедицию. Янов Юрий Миронович много лет занимался геологической съемкой. Прошел путь от коллектора до начальника партии, которым стал уже в 1963 г., возглавив геолого-съемочные и поисковые работы. Юрий Миронович руководил этими работами до 1985 г., менялись только объекты. Он всегда отличался требовательностью к себе и подчиненным. Юрий Миронович первый автор четырех Госу- дарственных геологических карт м-ба 1:200 000 первого поколения. Под его руководством был выявлен целый ряд месторождений меди и редких металлов. С 1985 г. Ю. М. Янов работал главным инженером геологической экспедиции во Вьетнаме. Ю. М. Янов скоропостижно скончался в 1997 г. Мария Федоровна Янова окончила биолого-почвенный факультет Воронежского университета и, приехав с мужем в Бурятию, стала работать в Центральной лаборатории Бурятского управления. При ее активном участии разрабатывались и внедрялись новые методики изучения химического состава руд, осваивались новые приборы.
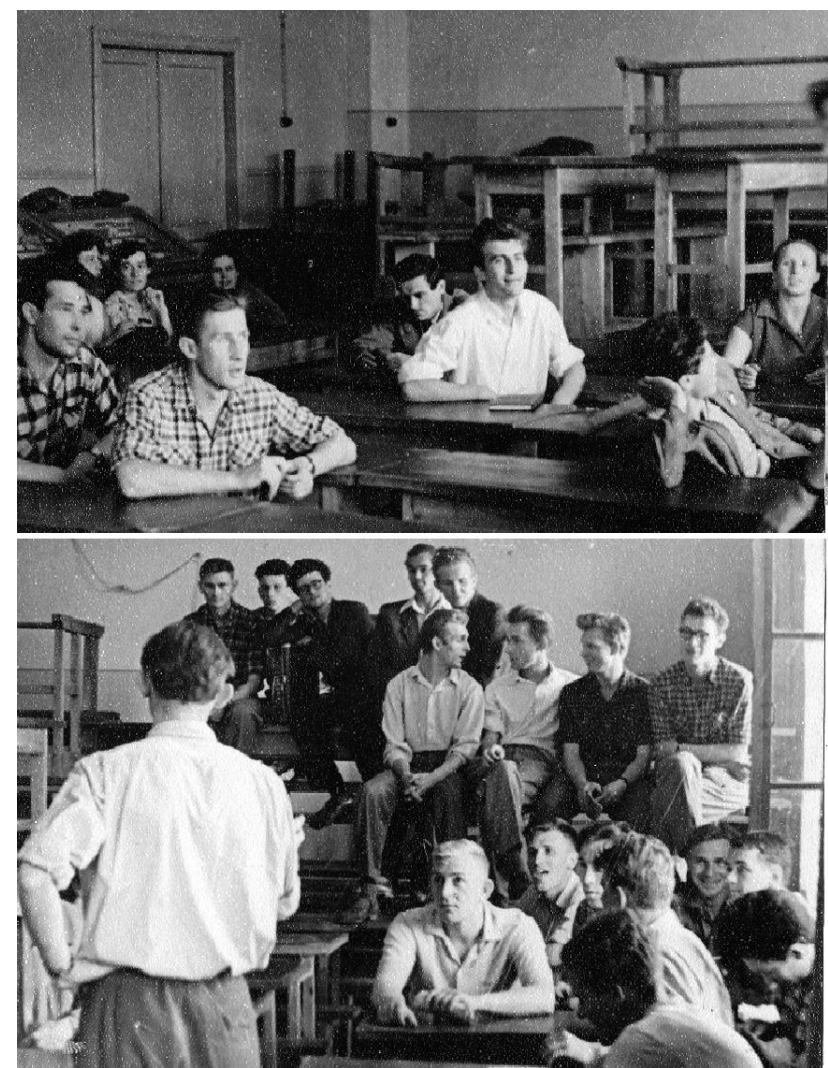

В аудитории Геологического факультета ВГУ, июнь, 1959 г.

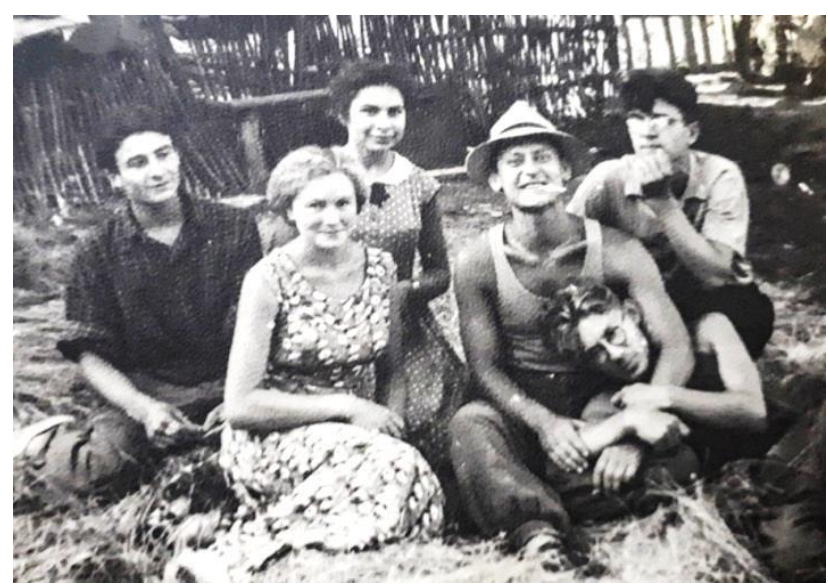

Выпускники геологического факультета 1959-1960 г2. (слева направо): Лев Максимов, Эмилия Максимова, Лилия Костромина, Юрий Холод, Эдуард Прудовский, Виталий Маняхин. 
В последующие годы в Бурятское геологическое управление приезжали работать целые группы молодых геологов. В 1959 г. свою трудовую деятельность в республике начали супруги Рейф, Козлов Ю. П., Сорокин В. А., Холод Ю. М., Филатов В. Г., Сотников Г.Д., Соколов О. В., Прудовский Э. Л., Шабалин М. И., в 1960 г. - супруги Максимовы, Гусев Ю. П., Бутов Ю. П., Лосицкий В. И., Маняхин В. П., Клевцова Н. Д., Костромина Л. А. и многие другие. Они вместе учились и вместе работали много лет, всегда дружили и поддерживали друг друга. Многие из них стали известными в Бурятии исследователями недр.

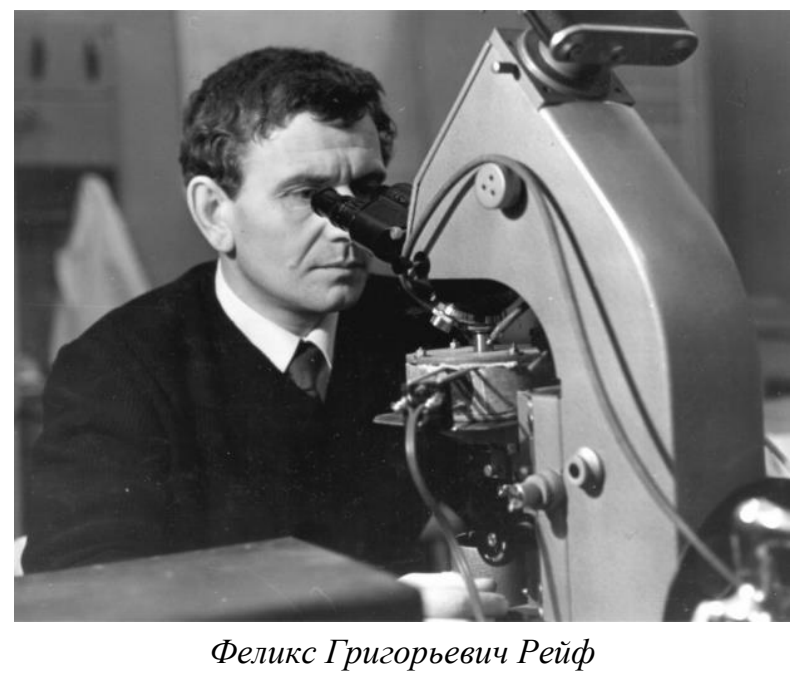

Одним из виднейших геологов-исследователей Байкальского региона стал Рейф Феликс Григорьевич. В 1959 г., после окончания Воронежского госуниверситета молодые геологи Феликс Григорьевич и Людмила Ивановна Рейф приехали в Бурятию. Они были направлены в Геологическую экспедицию и начали работать коллекторами в партии, занимающейся геологической съемкой и поисками масштаба 1:200 000. Уже 1961 г. Феликс Григорьевич стал начальником партии и первым авторов Государственной геологической карты. До 1970 г. в должности начальника геологических партий Феликс Григорьевич вел геологическую съемку масштаба 1:50 000 в разных районах республики. Под его руководством выявлены и изучены десятки рудопроявлений, геохимических и геофизических аномалий. Уже в то время Феликса Григорьевича увлекла связь эндогенного оруденения с магматизмом. Собранный в эти годы материал стал основой кандидатской диссертации, которую он защитил в 1973 г. В этом же году Феликса Григорьевича пригласили на работу в Геологический институт СО РАН, где в полной мере раскрылся его исследовательский и организаторский талант. Основным направлением научных исследований Ф. Г. Рейфа стало выяснение физико-химических условий генерации и кристаллизации магм, роли магматического процесса в формировании рудообразующих гидротермальных систем, локальное прогнозирование плутоногенных рудных месторождений методами термо- барогеохимии, а также развитие и усовершенствование методов исследования включений в минералах. Феликс Григорьевич сформировал новое в то время направление в исследовании процессов магмо- и рудообразования, основанное на экспериментальном и аналитическом изучении мельчайших включений минералообразующей среды (расплава или раствора) в минералах.

Характерной чертой работы Феликса Григорьевича было сочетание фундаментальных научных исследований с потребностями геологоразведочной и поисковой практики. С большой детальностью и присущей Феликсу Григорьевичу ответственностью исследованы практически все крупнейшие редкометалльные месторождения Забайкалья. Вместе с сотрудниками лаборатории он разработал новый (термобарогеохимический) метод локального прогнозирования месторождений вольфрама и молибдена. Под его руководством созданы термокамеры с силикатным нагревателем, позволяющие оценивать температуры кристаллизации расплавных и флюидных включений, разработана и апробирована оригинальная методика лазерноспектрального микроанализа индивидуальных флюидных включений на приборе LMA-1. На основе проведенных исследований в 1985 г. Феликс Григорьевич блестяще защитил докторскую диссертацию. В 19892003 гг. он заведовал лабораторией гранито- и рудообразования Геологического института. Ф.Г. Рейф опубликовал более 130 научных работ, среди которых пять монографий и десятки статей в ведущих отечественных и международных изданиях. Он был создателем одной из ведущих в России школы термобарогеохимических исследований, удостоен званий «Заслуженным деятель науки Российской федерации» и «Заслуженный деятель науки Республики Бурятия». Феликс Григорьевич уделял много внимания подготовке специалистов соответствующего профиля. Его открытость и широта знаний привлекала к нему исследователей из многих городов и стран. Под его руководством защищены четыре кандидатские диссертации.

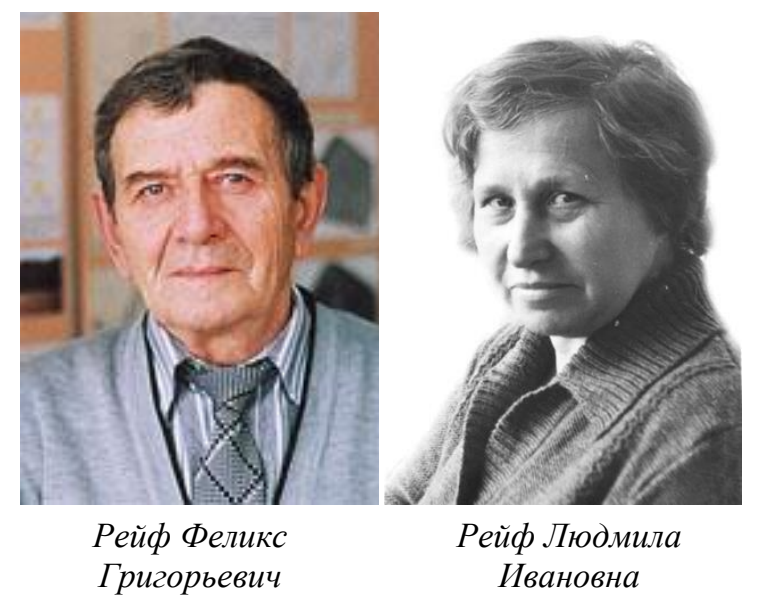

Все годы вместе с ним всегда была его верная спутница и соратница Людмила Ивановна Рейф. Людмила Ивановна всю жизнь работала в Центральной геоло- 
го-поисковой экспедиции. Она в совершенстве владела поисковыми методами полевых исследований, была высокопрофессиональным петрографом, его поддержкой и опорой. С ней они вместе прожили более 50 лет. 1 января 2008 г. Феликс Григорьевич ушел из жизни, Людмила Ивановна скончалась в 2017 году.

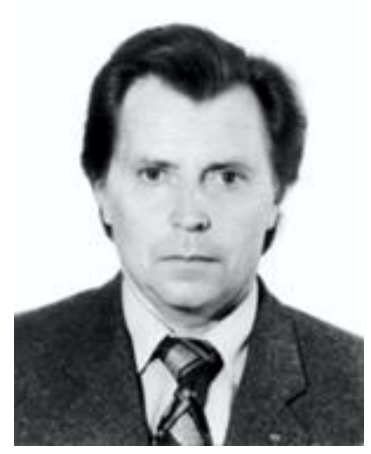

Сорокин Владимир Александрович
Сорокин Владимир Александрович свою трудовую деятельность, как и его сокурсники, начал в Геолого-поисковой экспедиции БГУ. Всю жизнь он посвятил изучению геологии республики. За личный вклад в развитие и становление геологической отрасли Бурятии, он награжден знаком «Отличник разведки недр». Владимир Александрович десять лет занимался геологической съемкой масштаба 1:200 000 в труднодоступных районах Северобайкалья. Он прошел путь от старшего коллектора, геолога, начальника поискового отряда, старшего геолога, начальника партии, которым он стал уже в 1962 г. Под его руководством в полосе трассы Байкало-Амурской магистрали были выявлены перспективные рудопроявления - Огневское ртутное, Верхне-Ангарское золота и другие. Владимир Александрович является первооткрывателем Олдакитского марганцевого месторождения, автором и соавтором пяти листов Государственной геологической карты СССР масштаба 1:200 000 первого поколения и редактором двух листов ГГК200/2. С 1971 г. он перешел на работу в геологический отдел Геологосъемочной экспедиции, курируя все виды геологических работ. В. А. Сорокин внедрял и контролировал осуществление новой методики групповых геологосъемочных работ и аэрофотогеологического картирования масштаба 1:50 000. Владимир Александрович исключительно ответственный, грамотный специалист с аналитическим складом ума, творческим подходом к любому вопросу, что позволяло ему всегда находить наиболее рациональные пути решения вопросов, как при геологических исследованиях, так и в организации труда. С 1984 по 2008 гг. В. А. Сорокин руководил работой отдела «Территориальный геологический фонд» Бурятского филиала ФБУ «ТФГИ по Сибирскому федеральному округу». Богатый опыт и обширные знания по геологии Республики и компетентность в сфере законодательства и управления позволили ему организовать работу отдела на высоком уровне. Он фактически являлся редактором огромного числа отчетов по всем видам геологических работ, проводимых на территории Бурятии. Богатыми знаниями и опытом В. А. Сорокин щедро делится с молодыми специалистами, и всегда готов дать консультацию по широкому кругу вопросов. Благожелательным, ровным отношением к коллегам, высокой эрудицией, принципиальностью В. А. Сорокин снискал всеобщее уважение среди геологов Бурятии. И по сей день Владимир Александрович работает в Бурятском территориальном геологическом фонде.

Шабалин Михаил

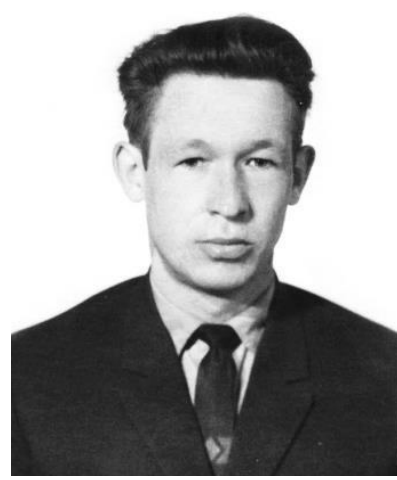
Иванович после окончания университета был зачислен в Геологопоисковую экспедицию и проработал в регионе более 33 лет. Михаил Иванович начал свой трудовой путь со скромной должности старшего коллектора, геолога и через 3 года стал начальником геологосъемочной партии, а

Шабалин Михаил Иванович позже главным инженером экспедиции. Он работал в разных районах республики, занимался геологической съемкой и поисками разного масштаба.

Михаил Иванович автор и соавтор трех листов Государственных геологических карт 1:200 000, шести геологических отчетов. Он является первооткрывателем Таширского бериллиевого и Хылтыгейского флюоритового месторождений, под его руководством изучены и оценены проявления Бутуйское берилиевое и Осеннее плавикового шпата, позже переведенные в ранг месторождений. В 1975 г. Михаил Иванович возглавил Геохимическую партию и в течение шести лет занимался обобщение геохимической информации по всему региону. По его инициативе было организовано и проведено всесоюзное совещание по геохимическим методам поисков. С 1981 по 1987 гг. Шабалин М. И. работал начальником партии в Советской геологической экспедиции в Монголии. Под его руководством проведена детальная разведка трех флюоритовых месторождений и подготовлена их эксплуатация. После возвращения из Монголии, Михаил Иванович возглавлял инженерную службу Центральной геологогеофизической экспедиции. За успешный труд он был награжден медалью «За трудовую доблесть», многочисленными грамотами МинГео СССР, Республики Бурятии и Правительства Монголии. С 1992 г. и до конца своих дней Михаил Иванович работал в Воронежском университете, передавая свой опыт и знания новым поколениям геологов. Он оставил заметный след в обобщении материала по минерагении ВКМ и разработке методики изучения закрытых территорий, является соавтором монографии «Минерагения территорий с двухъярусным строением».

Соколов Олег Васильевич с первых лет начал работать в одном из самых сложных и интересных районов Бурятии - Северо-Муйском. В качестве геолога и затем начальника поискового отряда Бамбуйской партии занимался геологическим картированием масштаба 1:200 000 и поисками. Им в первый же год работы здесь были обнаружены железо-титанванадиевые руды Витимконского габбро-норитового 


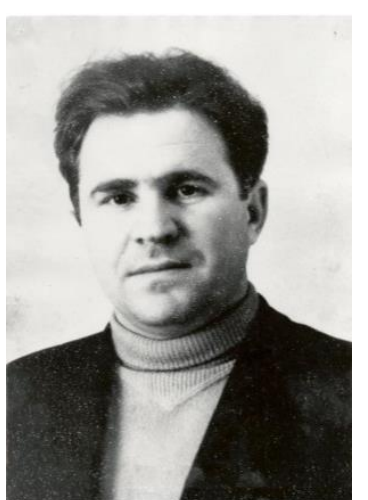

Соколов Олег

Васильевич

массива, медно-никелевая минерализация Маринкинского габброидного массива.

Под руководством Соколова О. В. была создана первая комплексная геолого-геофизическая Голюбекская партия с задачей геологического картирования масштаба 1:50 000 и поисков месторождений золота и других полезных ископаемых. Коллектив партии открыл крупные тела редкометалльных пегматитов, Голюбекское проявление светлоокрашенных нефритов, мощную Пашковскую зону с золотоносной кварцево-сульфидной минерализацией. В 1965 г. Соколов О. В. назначен начальником Зырянской партии, ведущей геологическое картирование и поиски в Прибайкальском районе. Под его руководством и при непосредственном участии установлены апатитоносность Зырянского габбро-диоритового массива, проявления кварцитов и фосфоритов. Олег Васильевич стал одним из первооткрывателей уникального Черемшанского месторождения кварцитов. Именно его целеустремленность, энергичность, умение работать с людьми позволили превратить этот объект в крупное месторождение всесоюзного значения. Отчет с подсчетом запасов был защищен им в ГКЗ СССР на «отлично». О. В. Соколову присвоено звание «Заслуженный инженер БурАССР». В 1973 г. О. В. Соколов уехал из Бурятии и продолжил свою трудовую деятельность в Иркутской области.

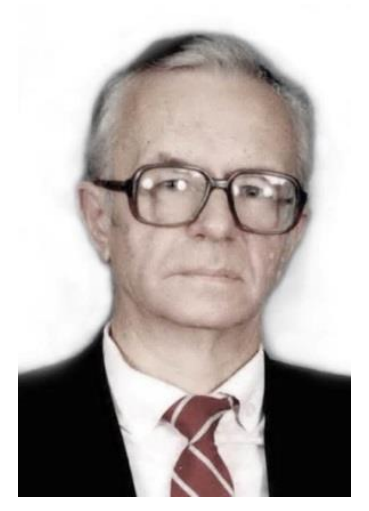

Юрий Петрович Козлов
Козлов Юрий Петрович тоже выпускник 1959 г., начал свой трудовой путь в Центральной геологосъемочной экспедиции и руководил крупномасштабной геологической съемкой в КурбиноЕравнинском рудном районе. В результате им на качественно новой основе была разработана Легенда Удино-Витимской серии листов, выделены и обоснованы новые стратиграфические подразделения, его имя, как автора новых стратиграфических подразделений, вписано в Стратиграфический словарь СССР. С 1975 г. Юрий Петрович связал свою геологическую судьбу с крайним севером Бурятии, возглавляя геологосъемочные и поисковые работы в Багдаринской, Северо-Муйской и Северо-Байкальской экспедициях. Особый вклад он внес в изучение геологии и полезных ископаемых зоны Байкало-Амурской магистрали. Под его геологометодическим руководством разведаны и подготовле- ны к эксплуатации месторождения строительных материалов, которые использовались при строительстве БАМа. С 1998 г. Ю. П. Козлов работал ведущим геологом ГФУП «Бурятгеоцентр». Им составлены карты полезных ископаемых для серии листов к ГГК-200/2, оценен ресурсный потенциал Витимконского рудного узла с ванадиеносными железотитановыми рудами и обоснована возможность создания в Бурятии, в зоне БАМа, мощной титановой провинции. Ю. П. Козлов является одним из авторов комплекта ГГК-1000/2, комплекта ГГК-1000/3 и автором карты золотоносности листа N-49, которой будет пользоваться еще не одно поколение геологов. Юрий Петрович относится к числу высокообразованных профессионалов, оставивших яркий след в создании современной геологической основы и минерально-сырьевого потенциала Бурятии и Российской Федерации. Результаты его 46летней геологической деятельности изложены в многочисленных отчетах, статьях и публицистических выступлениях. Труд Ю. П. Козлова отмечен тремя медалями, многочисленными грамотами, в 2001 г. ему присвоено звание «Отличник разведки недр». Скончался Ю.П. Козлов в 2005 году.

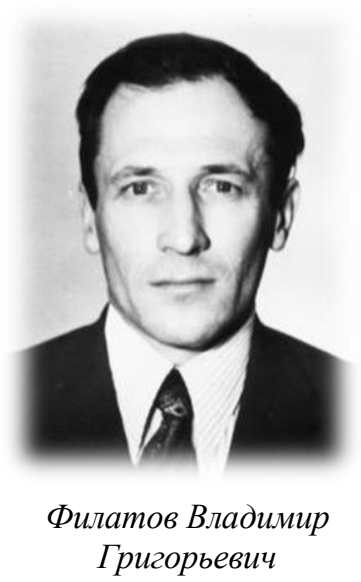

Филатов Владимир Григорьевич получил распределение в Бурятское геологическое управление, был зачислен, вместе с однокурсниками, в Геологосъёмочную экспедицию, и отправлен на работу старшим коллектором в Тункинскую партию. В 1960 г. Владимир Григорьевич уже был назначен старшим геологом, а затем и начальником поисково-съемочной партии в Северо-Байкальской экспедиции, а в 1979 г. стал главным геологом этой экспедиции. Это был самый напряженный, самый плодотворный период в работе экспедиции и большая ответственная нагрузка для главного геолога. Поисковые отряды вели поиски железных, молибденовых и оловянных руд, продолжали геологическую съёмку площадей. По заявкам БАМовских организаций велись поиски и разведка месторождений строительных материалов, устранялись проблемы на строительстве Северомуйского тоннеля. В 1985 г. В. Г. Филатовым был защищен в ГКЗ СССР отчет по крупному полиметаллическому Холоднинскому месторождению. В 1996 г. Владимир Григорьевич перешел на должность ведущего геолога по геологоразведочным работам. За добросовестный труд и значительный вклад в развитие геологоразведочной отрасли В. Г. Филатов награжден медалью «За строительство Байкало-Амурской Магистрали» и ему присвоено звание «Заслуженный Геолог Бурятии». В 2008 г. Владимир Григорьевич ушел из жизни на рабочем месте. 


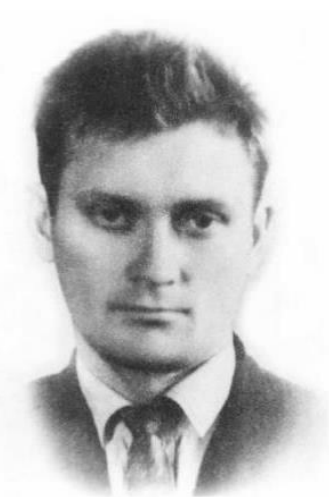

Холод Юрий Михайлович
Юрий Михайлович Холод свою геологическую деятельность в 1959 начал в Геологосъемочной экспедиции и сразу, благодаря своим глубоким теоретическим знаниям, организаторским способностям, творческим подходом к решению геологических вопросов, стал начальником партии.

Ю. М. Холод был инициатором разработки и внедрения в практику нового метода геологического картирования - групповой геологической съемки и поисков масштаба 1:50 000. Основные усилия он концентрировал на целенаправленных поисках. При его участии и под его руководством были открыты многочисленные рудопроявления и месторождения молибдена, такие как Жарчихинское, Харитоновское, Колобковское и др., флюорита Хэлтэйского рудного поля. Одновременно он занимался научной работой, изучал мезозойские вулканогенные и осадочные комплексы, опубликовал семь научных работ. В 1975 г. Юрий Михайлович был назначен начальником Окинской экспедиции, которой руководил до 1983 г. Юрий Михайловия внес значительный вклад в организацию разведочных работ Зун-Холбинского золоторудного и Ухагольского фосфоритового месторождений. Он добился решения Совмина Бурятской АССР о выделении средств на строительство автотрассы, связывающей поселки Монды, Орлик и основные объекты геологоразведочных работ. Его высокая внутренняя интеллигентность, тактичность, скромность, желание помочь каждому в решении тех или иных невзгод, чувство обостренной справедливости и умение находить выход из затруднительных ситуаций вызывало уважение всех работников экспедиции. В Окинской экспедиции он, не только как ее начальник, а и по масштабу личности, был на первом месте. В 1982-83 гг. Юрий Михайлович работал старшим геологом Селенгинской экспедиции, а затем был командирован в Монголию для оказания технического содействия в изучении недр, где в течение 5 лет возглавлял Эрдэнэтскую и Бэрхинскую партии Советской экспедиции. Под его руководством изучались глубокие горизонты и юго-восточный фланг медномолибденового месторождения Эрдэнтуин-Обоо флагмана горнорудной промышленности Монголии, завершалась разведка флюоритовых месторождений. За успешный труд его в МНР он удостоен звания «Передовой геолог МНР» и ряда правительственных наград. После возвращения в 1988 г. из загранкомандировки Ю. М. Холод был назначен заместителем генерального директора ПГО «Бурятгеология» по кадрам и социальному развитию. Им предпринимались энергичные меры по подготовке руководящих кадров из числа молодых специалистов, решению жилищных и иных проблем в геологической отрасли. Юрий Михайлович отличался активной жизненной позицией, не раз избирался членом партбюро и профкома, народным депутатом районного Совета Окинского района Бурятии. Он как ветеран труда ПГО «Бурятгеология», награжден медалями «За доблестный труд» и другими. В 1992 г. Ю. М. Холод был переведен на должность зам. генерального директора ПГО «Центргеология», а с 1995 г., выйдя на заслуженный отдых, переехал в г. Воронеж.

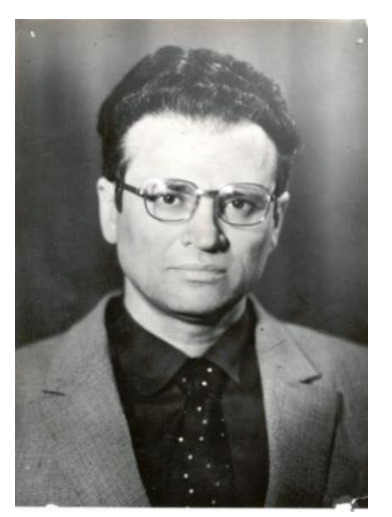

Прудовский Эдуард Леонидович
Эдуард Леонидович Прудовский начал свою трудовую деятельность в Геологосъемочной экспедиции, как и большинство его сокурсников, приехавших в Бурятию, прошел путь от коллектора до начальника партии. Работал на геологической съемке, возглавлял поисковый отряд, позже тематические работы по изучению хромитоносности Бурятии. Стал одним из первооткрывателей, вместе с Соколовым О. В., Черемшанского месторождения кварцитов. В 1971 г. поступил в аспирантуру при Институте земной коры СО АН СССР в г. Иркутске, и в 1974 г. защитил кандидатскую диссертацию, посвященную вопросам рудоносности дунит-троктолитовых комплексов Байкальской горной области. И в этом же году судьба «распределила» его в Окинскую экспедицию. Здесь он вначале занимал должность главного геолога Уха-Гольской партии, а с 1974 по 1981 гг. - главного геолога Окинской экспедиции, начальником которой он стал в 1981 г. Эдуард Петрович был достойным руководителем, сменив на этом посту Холода Ю. М., отстаивал интересы экспедиции на различных уровнях власти, представлял результаты ее работы на совещаниях и конференциях. Все геологи Окинской экспедиции с большим уважением относились к нему. Эдуард Петрович - блестящий геолог, хороший спортсмен, великолепный музыкант и просто обаятельный человек. Все его профессио-

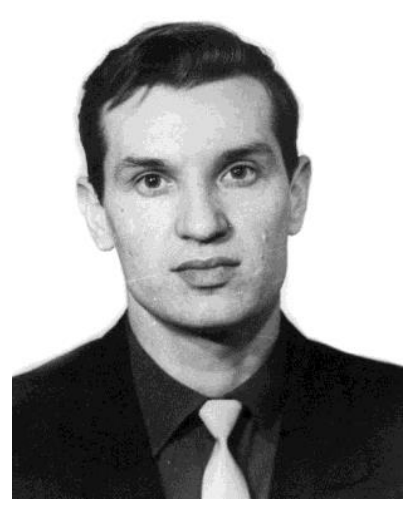

Гусев Юрий Петрович нальные навыки сполна проявились, когда он впоследствии возглавил геологическую службу Липецкой области.

В 1960 г. свою геологическую судьбу в Бурятии начал Гусев Юрий Петрович и посвятил почти 60 лет освоению недр республики. С 1960 по 1972 гг. он, сначала рядовым геологом, затем начальником поискового 
отряда и геологической партии занимался разномасштабным геологическим картированием и поисками, стал автором и соавторам ряда Государственных геологических карт, первооткрывателем Усутайского родонитового и Мохового оловянного месторождений. С 1972 г. Ю. П. Гусев был назначен главным геологом, а с 1977 г. - главным инженером Багдаринской экспедиции. При его умелом руководстве и непосредственном участии были подготовлены к освоению десятки россыпей золота, утверждены запасы крупнейших Ирокиндинского и Ципиканского золоторудных месторождений, Ауникского бериллиевого месторождения, открыто и предварительно разведано Ангокитское месторождение вольфрама. Много усилий и личного участия вложено в инженерногеологическое изучение трассы Байкало-Амурской магистрали, особенно района Северо-Муйского тоннеля. Под его руководством в то время был подготовлен к эксплуатации ряд, столь необходимых БАМу месторождения строительных материалов, изучены створы тоннеля. В 1980-85 гг. Юрий Петрович работал в Монголии главным геологом группы советских специалистов при Министерстве геологии и горнорудной промышленности страны, руководил геологической съемкой, поисками и разведкой ряда месторождений полезных ископаемых. При его активном участии был значительно расширен минеральносырьевой потенциал Монголии, разработана долгосрочная программа развития геологической отрасли. Юрий Петрович был награжден двумя медалями и удостоен звания «Почетный геолог Монголии». С 1987 г. Ю. П. Гусев назначен главным геологом Центральной геолого-геофизической экспедиции (ранее Геологосъемочной). Под его руководством разведаны и переданы для освоения многие месторождения, наиболее значимые из них - вольфрамо-молибденовое Малый Ойногор, свинцово-цинковое Даваткинское, барит-стронцианитовое Халютинское, золоторудное Юбилейное. В годы постсоветских реформ главное внимание Юрий Петрович уделял созданию комплектов геологических карт нового поколения. Гусев Ю. П. был высокопрофессиональным, разносторонним геологом, сочетающим знания и большой опыт организации и ведения всего цикла работ - от регионального картирования до детальной разведки месторождений. Он автор семи и соавтор 12 геологических отчетов, 19 научных статей, посвященных геологии и минерально-сырьевому комплексу Бурятии. За огромный личный трудовой вклад в развитие минерально-сырьевой базы России и республики Бурятия Юрий Петрович Гусев был удостоен почетных званий «Заслуженный геолог Российской Федерации» и «Заслуженный геолог Бурятской АССР», награжден знаками «Почетный разведчик недр СССР», «Почетный разведчик недр РФ», многочисленными грамотами и медалями Российского и республиканского значений. Юрий Петрович с многогранной профессиональной работой сочетал и общественную деятельность.
Большой заслугой Юрия Петровича является воспитание молодых геологов, приходящих в экспедицию после окончания техникумов и вузов. Высокопрофессиональный специалист, доброжелательный и душевный человек, он был наставником целой плеяды специалистов, которых

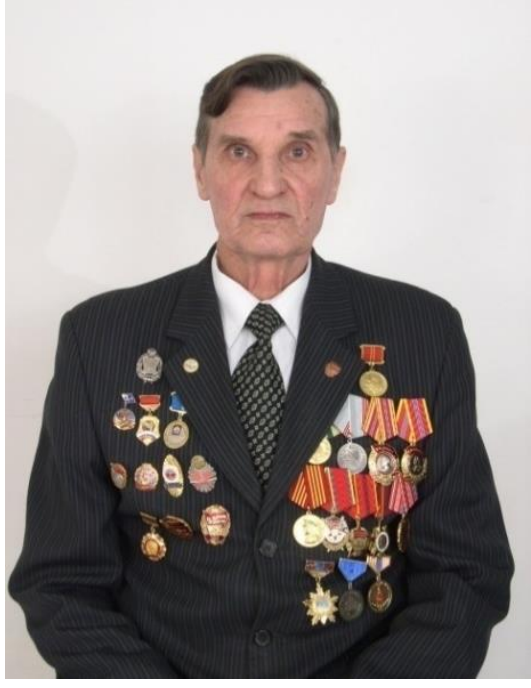

Гусев Юрий Петрович научил профессиональным навыкам и помог достичь собственных высот в нелегкой профессии геолога. Конечно, особенно опекал он выпускников Воронежского университета. Именно он поддерживал и направлял мою работу как геолога-биостратиграфа, при его участии в Центральной экспедиции была организована лаборатория микропалеонтологических исследований. Юрий Петрович придавал большое значение при геологическом картировании стратиграфическим и палеонтологическим исследованиям. Ю. П. Гусев был эрудированным профессионалом, всегда готовым прийти на помощь, поделиться своими энциклопедическими знаниями и опытом с коллегами. К нему можно было обратиться по любому вопросу - он знал все, помогал, подсказывал, направлял. Юрий Петрович Гусев скончался в 2019 г.

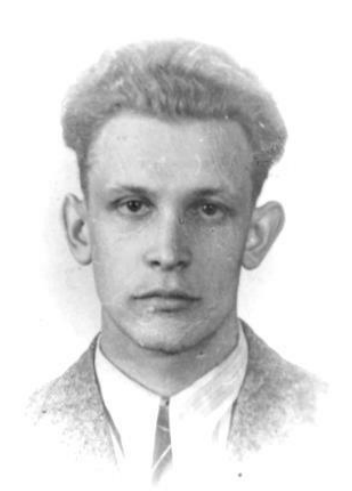

Маняхин Виталий Петрович
Маняхин Виталий Петрович с отличием окончил геологический факультет и вместе с однокурсниками местом работы выбрал Бурятию. В 1960 г. он был зачислен в Геологопоисковую экспедицию и работал в ней до завершения своей трудовой деятельности в 1994 г. С первых лет работы Виталий Петрович зарекомендовал себя как грамотный специалист, умело сочетающий глубокие теоретические знания с кропотливыми полевыми исследованиями. С 1963 г. он продолжал работать уже старшим геологом в геологических партиях, выполняя геологическую съемку масштабов 1:200 000 и 1:50 000. Виталий Петрович всегда стремился детальнее изучить геологическое строение района, был сторонником комплексного использования всех доступных методов геолого-геофизических, геохимических, литоло-фациальных, палеонтологических ис- 
следований. В. П. Маняхин обладает высокой профессиональной квалификацией и работоспособностью, добросовестностью, принципиальностью и ответственностью. Много внимания Виталий Петрович уделял подготовке молодых кадров, делясь своим опытом и знаниями. В. П. Маняхиным открыто и оценено Мало-Убукунское редкометальное месторождение, Большое Куналейское рудопроявление молибдена. Виталию Петровичу принадлежит первая находка девонской морской фауны в хребте Хамар-Дабан. Он автор и соавтор многочисленных отчетов и Легенды Селенгинской серии листов. В 1970 г. В. П. Маняхин был признан лучшим по профессии в Бурятском геологическом управлении, а в 1975 г. ему присвоено звание «Лучший геологосъемщик БГУ», он награжден многочисленными грамотами. В настоящее время Виталий Петрович находится на заслуженном отдыхе.

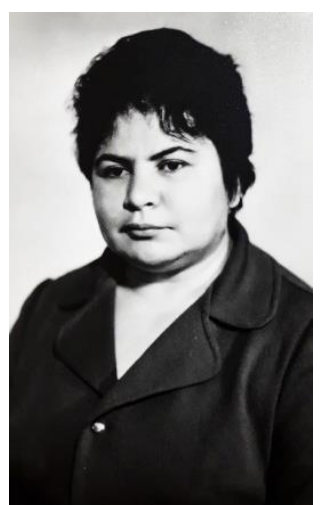

Максимова Эмилия Андреевна
В августе 1960 г. прибыли в БГУ Максимовы Эмилия Андреевна и Лев Павлович. Они были направлены в Тематическую экспедицию, а в 1962 г. переведены в Геологосъемочную экспедицию. Эмилия Андреевна всю жизнь проработала в Бурятском геологическом управлении, сначала геологом, а затем главным геологом Опытно-методических партий Центральной и Геофизической экспедиций. С 1991 г. она возглавляла геологическую службу в партии, занимающейся внедрением автоматизированной обработки геологической информации. Эмилия Андреевна занималась изучением вещественного состава и петрофизических свойств магматических пород и руд, была создателем баз данных по золотоносным россыпям Республики Бурятии и базы для хранения поисково-съемочной информации. В 1985 г. была приглашена для оказания методической помощи геологам в республику Мозамбик. Возвратившись на родину, поступила в аспирантуру при Бурятском научном центре, окончив ее в 1992 г., защитила кандидатскую диссертацию, посвященную изучению акцессорных минералов и элементовпримесей в мезозойских гранитоидах Забайкалья. Э. А. Максимова обладала глубокими теоретическими знаниями, великолепной профессиональной подготовкой, была высоко эрудированным человеком с живым юмором, добрым и терпеливым наставником. Она всегда принимала активное участие в общественной жизни экспедиции, была неизменным победителем шахматных спартакиад. Эмилия Андреевна скоропостижно скончалась в 1997 г. Лев Павлович Максимов в 1964 г. получил квалификацию геолога-геохимика, закончив курсы в Иркутском университете, и был назначен старшим геологом геохимической партии. А в 1966 г. он уехал из Бурятии.

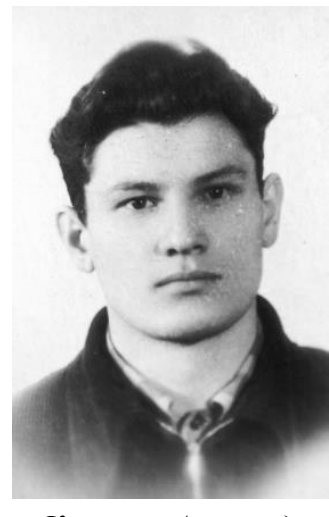

Кузнецов Александр Николаевич
Кузнецов Александр Николаевич окончил геологический факультет в 1960 г. и уже в августе вместе с супругой Нинель Степановной, тоже выпускницей филологического факультета Воронежского университета, и маленькой дочерью прибыли в Улан-Удэ. Александр Николаевич еще студентом проходил преддипломную практику в Темникской партии БГУ и при распределении выбрал Бурятию. В геолого-поисковую экспедицию он был зачислен на должность техника и за довольно короткое время стал начальником отряда и затем старшим геологом. А. Н. Кузнецов обладал глубокими теоретическими знаниями, которые с успехом применял в своей практической работе. Под его руководством были выявлены и изучены многочисленные рудопроявления на Витимском плоскогорье. Особенно его интересовали металлогеническая специализация разновозрастных гранитоидных комплексов. Тогда и проявилась его склонность к научному анализу. Он увлеченно изучал вещественный состав гранитоидов, много времени уделял разработке их классификации, анализу акцессорных минералов, условиям кристаллизации гранитных магм и влиянию их на рудообразующие процессы. Александр Николаевич впервые в Бурятии выделил и охарактеризовал нефелино-сиенитовые мигматиты, формирующиеся в зоне экзоконтакта сиенитов. Александр Николаевич всегда принимал активное участие в общественной и спортивной жизни экспедиции. Его эрудиция, скромность, трудолюбие, дисциплинированность, честность, доброжелательность вызывали всеобщее уважение. В 1978 г. семья Кузнецовых переехала в г. Воронеж, где Александр Николаевич продолжил свою трудовую деятельность в должности доцента кафедры минералоги и петрологии геологического факультета ВГУ.

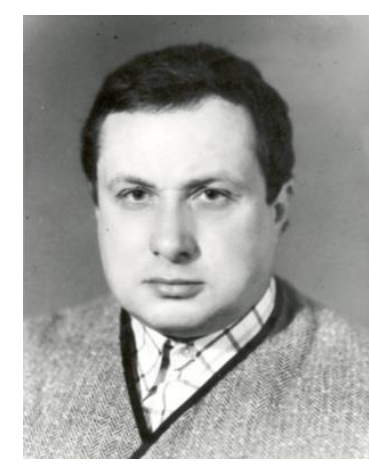

Бутов Юрий Павлович
Бутов Юрий Павлович свою трудовую деятельность начал в Геологосъемочной экспедиции. Он работал геологом, старшим геологом на геологической съемке, позже возглавлял ревизионно-поисковые и тематические работы на осадочные полезные ископаемые. Занимался изучением кор выветривания, поисками фосфоритов, бокситов, железо-марганцевых руд в Южно-Муйском, Икатском и Морском хребтах. Детальное изучение разрезов стратифициро- 
ванных толщ, многочисленные находки остатков трилобитов и археоциат кембрия, позволили Юрию Павловичу доказать широкое распространение нижнепалеозойских осадочных и вулканогенно-осадочных формаций в северо-западной части Витимского плоскогорья. Эти материалы стали основой кандидатской диссертации, которую он защитил в 1969 г., без отрыва от производства. С 1972 г. основным объектом его интересов стала юго-восточная часть Восточного Саяна. Ю. П. Бутов является первооткрывателем двух крупных месторождений в Восточном Саяне - Харанурского фосфоритового и Яматинского гематитовых кварцитов. В 1984 г. Юрий Павлович перешел работать в Геологический институт СО РАН. Основным направлением его научной деятельности стало продолжение изучения геологического строения и геологической истории развития Саяно-Байкальской горной области (СБГО) - традиционно считавшейся восточной частью тектонотипа байкальской складчатости. Многочисленные находки Ю. П. Бутовым и его коллегами остатков кембрийской фауны в толщах, традиционно считавшихся докембрийскими, позволили обосновать значительную роль каледонид в истории развития всего региона, пересмотреть схемы стратиграфии, внести значительные коррективы на геологические карты. Ю. П. Бутовым была разработана концепция домезозойской геологической истории региона, по которой территория СБГО в рифеесреднем палеозое развивалась в рамках одного геотектонического цикла, завершившегося в позднем палеозое. Результатом этих исследований стала докторская диссертация, которую Юрий Павлович защитил в 1993 г. Он - автор 4 монографий и более 70 статей. Юрий Павлович уделял много внимания подготовке специалистов соответствующего профиля. Он был частым гостем геологического факультета ВГУ, сотрудничал с коллегами с кафедры общей геологии и палеонтологии, приглашал на практику студентовгеологов. Его школу прошел ни один выпускник геолфака ВГУ. Ю. П. Бутов ушел из жизни 28 мая 2000 г. Юрий Павлович стал и моим первым настав-

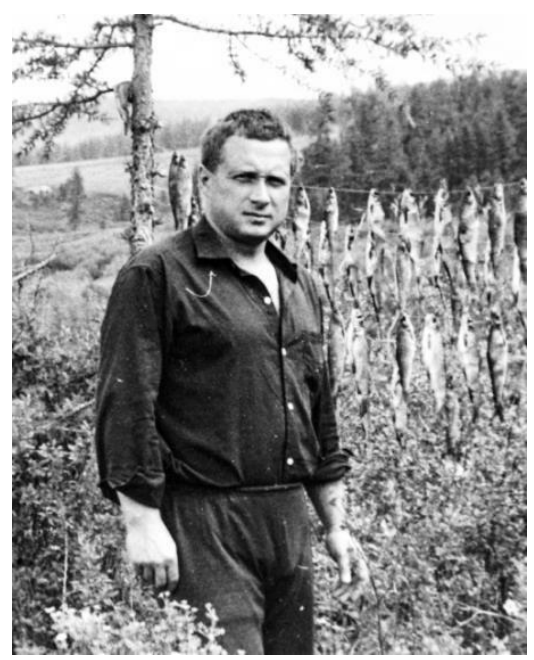

Бутов Юрий Павлович в поле ником и уителем.

Выпускники воронежцы шестидесятых годов двадцатого века оставили яркий след в изучении недр республики Бурятии, значительно умножив ее минерально-сырьевую базу.

Все последующие годы существования Бурятского геоло- гического управления воронежцы, работавшие в Бурятии, не теряли связи с родным геологическим факультетом. В БГУ на практику постоянно приезжали целые группы студентов, многие возвращались в Бурятию уже молодыми специалистами.

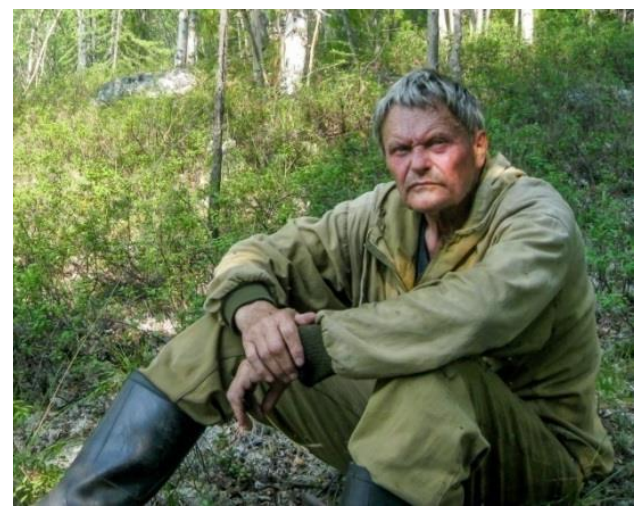

Ивлев Анатолий Степанович

После окончания Воронежского университета в 1974 г. в Бурятию приехал Ивлев Анатолий Степанович. И вот уже более 43 лет он занимается изучением ее недр. Анатолий Степанович был направлен в Аэрокосмогеологическую партию Центральной (Геологосъемочной) экспедиции и до 1990 г. вместе с коллегами активно внедрял в геологическую практику методику аэрофотогеологического картирования. Он принимал активное участие в аэрофотокартировании масштаба 1:50 0000 Верхне- и Нижне-Ангарской, Муйской впадин (трасса БАМ), Баргузинской и УстьБаргузинской впадин и их горного обрамления, Тункинской впадины и Юго-Восточного Прибайкалья на площади около 40 тыс. км². С 1991 по 1994 гг. А. С. Ивлев руководил тематической группой по практическому применению материалов аэрокосмических съемок при производстве геологосъемочных, экологических и поисковых работ в различных природноклиматических и ландшафтных условиях Бурятии. Начиная с 1995 г., Анатолий Степанович руководит геологосъемочными работами в Южно-Муйском районе, прогнозно-поисковыми работами в СевероМуйском районе, геохимическими и поисковыми работами в Джидинском районе. А. С. Ивлев в настоящее время продолжает активно трудиться. С 2010 г. Анатолий Степанович выполняет работы по составлению комплектов Госгеолкарт-200/2 на площади 4-х номенклатурных листов в Восточном Саяне. Он автор 4-х и соавтор 8-ми геологических отчётов, им составлено 8 листов карт четвертичных образований масштаба 1:200 000/2. А.С. Ивлев награжден знаком «Отличник разведки недр».

В 1978-1980 гг. в Бурятское геологоуправлении приезжали на работу молодые геологи-воронежцы Белоусов В. А., Димиденко А. И., Гришин А. А., Крахин А. А., Копейкин Ю. М., которые работали в Бурятии недолго и сделали достойную карьеру в других регионах России. 

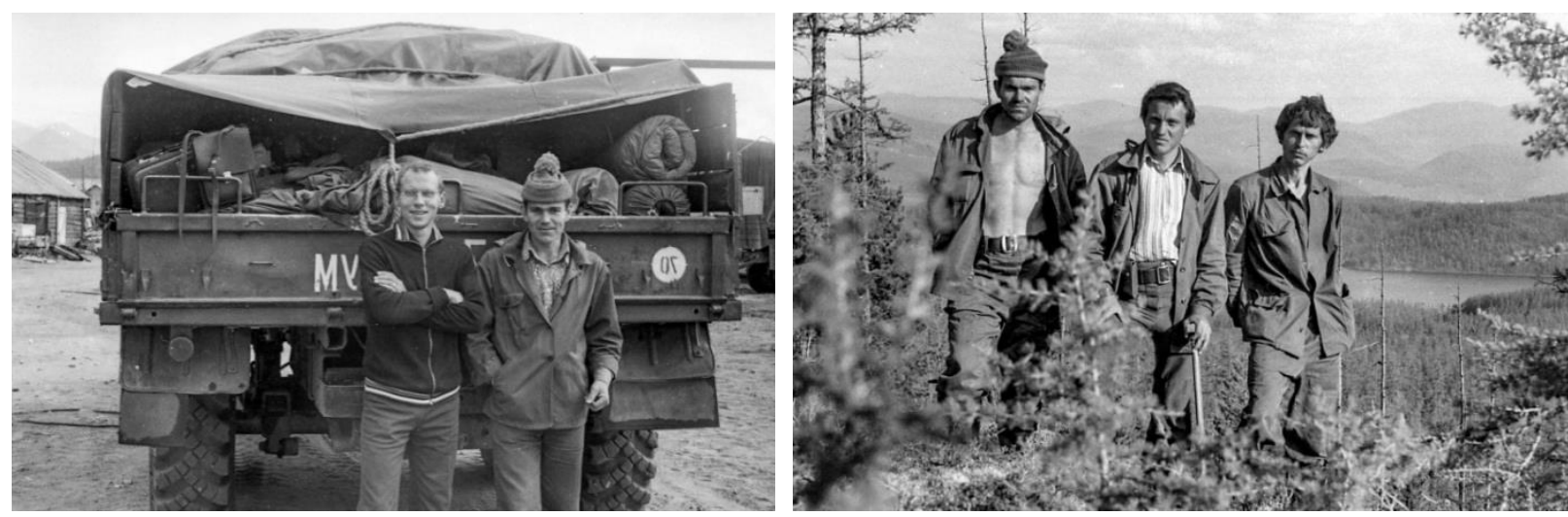

Восточный Саян, 1980 г. Слева направо: Копейкин Ю.М. (фото 1), Скопинцев В.Г., Рогачев А.М., Белоусов В.А. (фото 2).

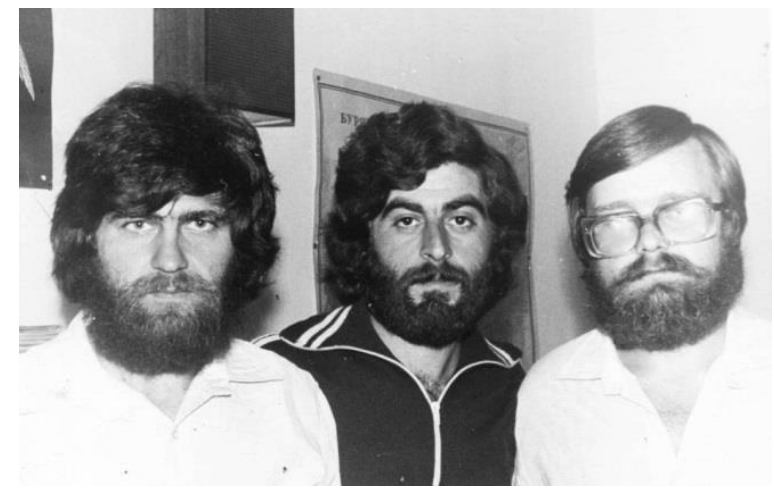

Геологи (слева направо): Крахин Александр, Чоговадзе Амиран, Гришин Анатолий после полевых работ, 1983 г

Копейкин Юрий Михайлович в настоящее время руководит работой Воронежской экспедиции. Демиденко Александр Иванович в 1984 г. возвратился в г. Воронеж и преподавал общую геологию в Воронежском архитектурно-строительном университете. Гришин Анатолий в это же время тоже уехал в Воронеж и сменил профессию. Геологическую династию отца продолжил сын Крахина Александра (скоропостижно скончался в 1986 г.) - Крахин Алексей, который работает в настоящее время в золотодобывающей отрасли Бурятии.

Свою геологическую деятельность в Бурятии до

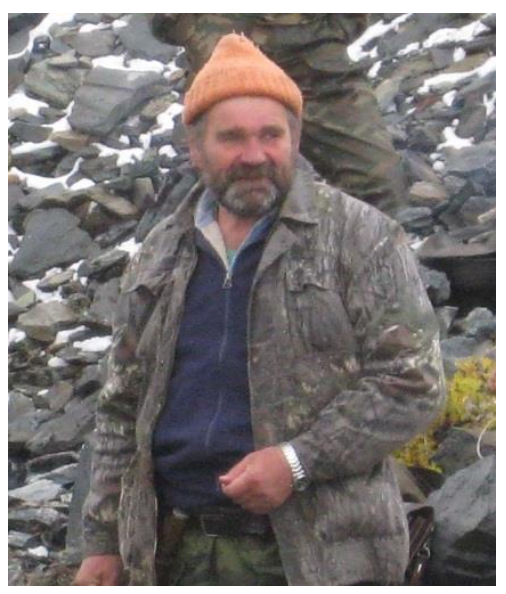

Скопинцев Виктор Германович настоящего времени продолжают выпускники геологического факультета ВГУ Скопинцев В. Г., супруги Минины, Косинова О. С.

Скопинцев Виктор Германович после окончания Воронежского университета в 1980 г. был направлен в Окинскую экспедицию, где начал работать геологом в Хара-
Нурской партии. Он сразу же включился в подготовку материалов к ТЭО кондициям по Хара-Нурскому месторождению фосфоритов. А в 1981 г. был переведен на геологосъемочные работы масштаба 1:50 000, которыми занимался до 1993 г. в должности геолога, начальника отряда, старшего геолога. В это время им выявлено Баргутэйское проявление корундовых наждаков, составлена кондиционная Геолкарта-50 района Зун-Холбинского месторождения золота, спустя почти полвека подтверждены находки алмазов в Восточном Саяне. В 1989 г. В. Г. Скопинцев возглавил Самартинскую партию и вел работы по составлению ГКК-200/2. При его непосредственном участии в это время выявлены и изучены проявления гранулированного кварца нового генетического типа, и выделена Восточно-Саянская кварцевоносная провинция с уникальными прогнозными ресурсами. С 1993 г. Виктор Германович в качестве ответственного исполнителя продолжает картосоставительские работы, разрабатывает легенду бурятской части Восточно-Саянской серии листов к ГГК-200/2. С 1999 г. эти работы ведлись уже в составе ГФУП «Бурятгеоцентр» (г. Улан-Удэ). В 2003-2007 гг. он руководил прогнозно-поисковыми работами на рудное золото в западной части Шумакской золоторудной подзоны. С 2008 г. Виктор Германович возглавляет работы по геологической интерпретации материалов комплексной аэрогеофизической съемки Витимского ураново-рудного района. В настоящее время В. Г. Скопинцев руководит картосоставительскими работами по составлению комплектов ГГК - 200/2 (второе издание) на площади 4-х номенклатурных листов в Восточном Саяне. Виктор Германович автор и соавтор 18 геологических отчётов по ГСР-50, ГДП-200, -1000 , поисковых и разведочных работ, 10 научных статей на различные темы. За вклад в развитие минерально-сырьевой базы России В. Г. Скопинцев награжден знаком «Отличник разведки недр».

После окончания Воронежского университета в 1981 г., по приглашению Бутова Юрия Павловича на работу в Бурятию приехали мы, Виктор и Ольга Минины.

Минин Виктор Васильевич, будучи студентом, в 1979-80 гг. проходил полевую практику в Восточном 


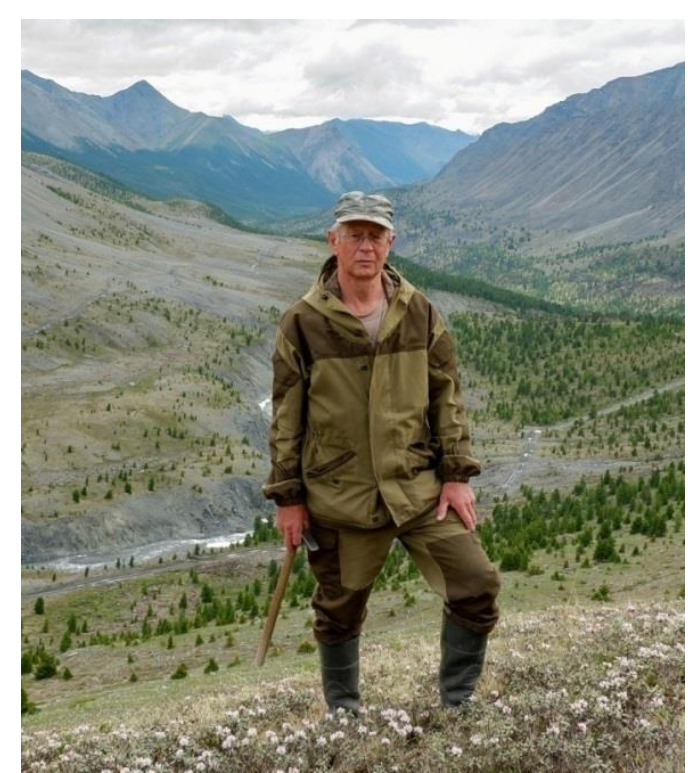

Минин Виктор Васильевич

Саяне. Его руководителем тогда был Бутов Юрий Павлович, а в отряде работал, тогда еще молодой специалист Белоусов Владимир, тоже выпускник Воронежского университета. С 1981 до 1994 гг. Виктор Васильевич работал в Центральной геологосъемочной экспедиции, сначала в должности геолога, позже начальника геохимического и поискового отрядов занимался геологической съемкой, поисками полиметаллов, редких металлов, рудного золота и олова. В 1994 г. был приглашен на работу в Комитет Природных Ресурсов Бурятии на должность ведущего специалиста, затем главного специалиста по поисковым работам на рудное золото, курируя все работы, связанные с поисками, разведкой и добычей этого металла в республике. В Комитете он проработал до 2004 г. Дальнейшая геологическая деятельность Минина В. В. была связана с поисково-разведочными работами в различных организациях на рудное и россыпное золото в Восточном Саяне и северных районах Бурятии. В настоящее время Виктор Васильевич работает главным геологом в ООО «Минерал», где занимается поисково-разведочными работами на нефрит в Восточном Саяне и Баунтовской тайге.

Я, Минина Ольга Романовна, с маленькой дочерью поехала в Бурятию за мужем, и честно, чувствовала себя декабристкой. Однако еще вовремя учебы в университете Юрий Павлович Бутов выбрал и для меня занятие, «пристроил» в палинологическую лабораторию. И определил мою дальнейшую специализацию как палинолога и биостратиграфа, за что я ему очень благодарна. Многие годы моей как производственной, так и научной работы связаны с Юрием Павловичем. Он учил меня работать в поле, думать, писать, а главное передал свое «чутье» и умение находить фауну. Юрий Павлович, работая уже в геологическом институте, пригласил меня сначала в аспирантуру, а затем на работу в лабораторию стратиграфии. Он стал научным руководителем моей канди- датской диссертации, посвященной обоснованию девонского этапа в геологическом развитии Западного Забайкалья. Защитила я еe уже после его кончины в 2003 г. И до настоящего времени я продолжаю начатое им дело занимаюсь изучением стратифицированных толщ, определением их возраста, формационной принадлежности. В 1996 г. я начала рабо-

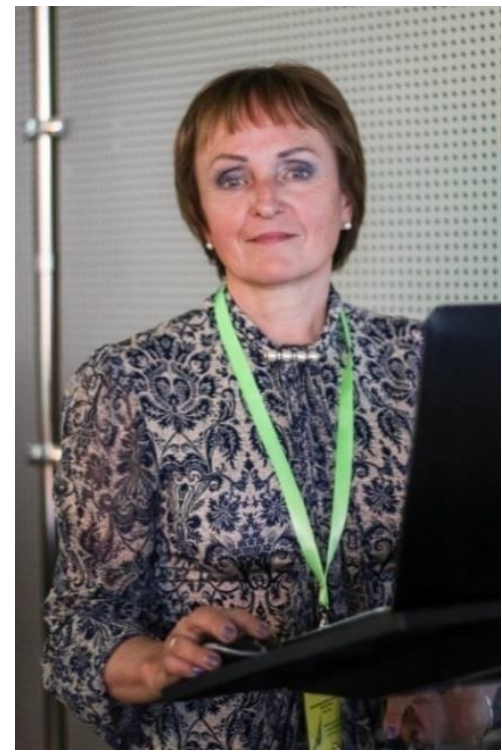

Минина Ольга Романовна тать в лаборатории геодинамики ГИН СО РАН, организованной д.г.-м.н., чЛ. кор. И. В. Гордиенко, который до настоящего времени является бессменным руководителем работ по изучению эволюции магматизма и седиментогенеза Монголо-Забайкальского региона. Детальное изучение стратифицированных образований, находки остатков фауны и флоры, палинологические исследования позволили, мне вместе с коллегами обосновать широкое распространение отложений девон-карбона, которые были выделены теперь уже среди полей развития докембрийских и кембрийских образований. Новые материалы стали основой для пересмотра схемы стратиграфии палеозоя Западного Забайкалья. Мне вообще очень повезло, в первые годы моей геологической деятельности в Бурятии я работала с талантливыми бурятскими геологами-стратиграфами Бутовым Ю. П., Далматовым Б. А., Осокиным П. В., Гусаревичем Г. А, Катюхой Ю. П., Филимоновым А. В., у которых многому научилась. Годы (2005-2012) совместной работы с выдающимися геологами из ГИН РАН Руженцевым С.В., Аристовым В. А., Некрасовым Г. Е. стали определяющими в моей дальнейшей работе. Под руководством Сергея Васильевича Руженцева, основываясь на новых данных о возрасте осадочных и магматических формаций, была разработана принципиально новая модель геодинамического развития Западного Забайкалья в первой половине позднего палеозоя. Эти материалы и стали основой докторской диссертации, которую я защитила в 2014 г. До настоящего времени я работаю в Геологическом институте СО РАН (г. Улан-Удэ), возглавляю лабораторию геодинамики, преподаю на кафедре Геологии в Бурятском госуниверситете.

Кузнецова (Тылосова) Софья Александровна продолжила геологическую деятельность своего отца Кузнецова Александра Николаевича. После окончания университета в 1989 г. молодой геолог Софья 


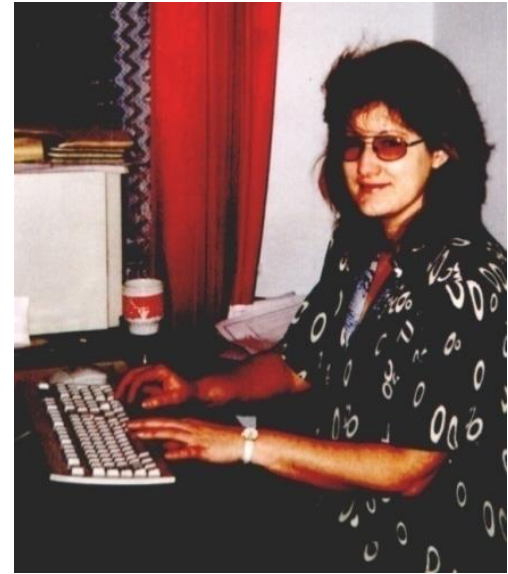

Кузнеиова (Тылосова)

Софья Александровна
Александровна выбрала местом работы Бурятию, где живет и в настоящее время. Софья родилась в г. Улан-Удэ в 1967 г., окончила здесь начальную школу. Продолжила она свое образование в г. Воронеже, куда переехали родители и, после окончания 10 классов, поступила на геологический факультет Воронежского университета. С. А. Кузнецова в 1982 г. была принята геологом в Центральную геолого-геофизическую экспедицию и проработала в ней на геологической съемке и поисковых работах более 20 лет. Софью Александровну отличали трудолюбие, инициативность, ответственность, творческий подход к порученному делу. Она унаследовала от отца интерес к магматическим породам и занималась петрографическим и петрохимическим изучением интрузивных комплексов, их металлогенической специализации.

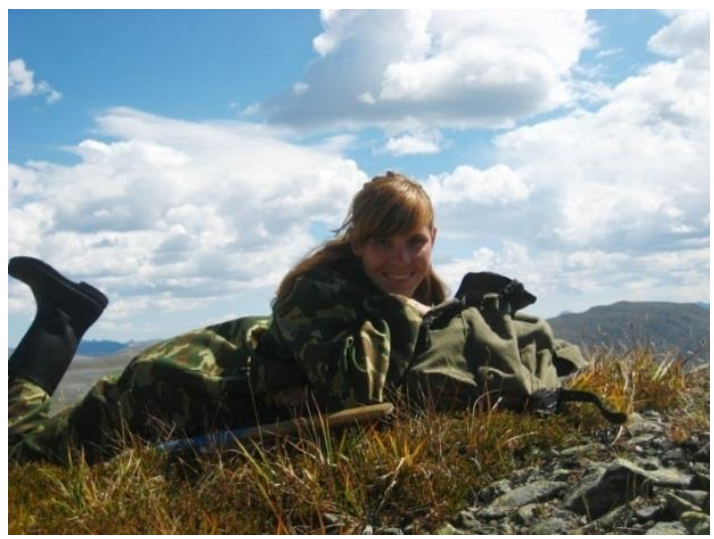

Косинова (Курбатова) Ольга Сергеевна

В 2008 г. в Бурятию приехала выпускница геолфака ВГУ Косинова (Курбатова) Ольга Сергеевна и связала свою жизнь с этим краем. Она была принята геологом в Багдаринскую партию ГФУП «Бурятгеоцентр», в которой в то время работала и я. С первых дней работы проявились все ее качества, которые так характерны для большинства воронежских выпускников - работоспособность, отличная профессиональная подготовка, высокая эрудиция, добросовестность и ответственность. Добрая, терпеливая, улыбчивая она сразу завоевала уважение и доверие всех, кто с ней работал. Потом два года Ольга Сергеевна работала на севере республики в Баунтовском районе, принимала участие в поисках коренных источников золота на Варваринской площади, в разведочных работах на крупнейшем золоторудном Ирокиндинском место- рождении. С 2011 по 2014 гг. в составе ООО «ВВС» принимала участие в полевых работах и занималась подготовкой проектов на поисковые и разведочные работы на россыпное и рудное золото и другие полезные ископаемые, и затем отчетов с подсчетом запасов по результатам разведочных работ в качестве ответственного исполнителя. С 2014 г. и до настоящего времени О. С. Курбатова руководит отделом Информационного обеспечения недропользования Бурятского филиала ФБУ «Территориальный фонд геологической информации по Сибирскому федеральному округу». Знание геологии Бурятии, аналитический склад ума, творческий подход к любому вопросу, доброжелательность и ответственность позволили ей организовать работу отдела на высоком уровне.

К сожалению, в «перестроечный период» резко сократился объем геологических работ, распались все региональные геологические организации республики и молодые специалисты оказались невостребованными. Но на практику в Бурятию все же постоянно приезжали студенты ВГУ, проводились совместные исследования с преподавателями и сотрудниками Геологического факультета Воронежского университета.

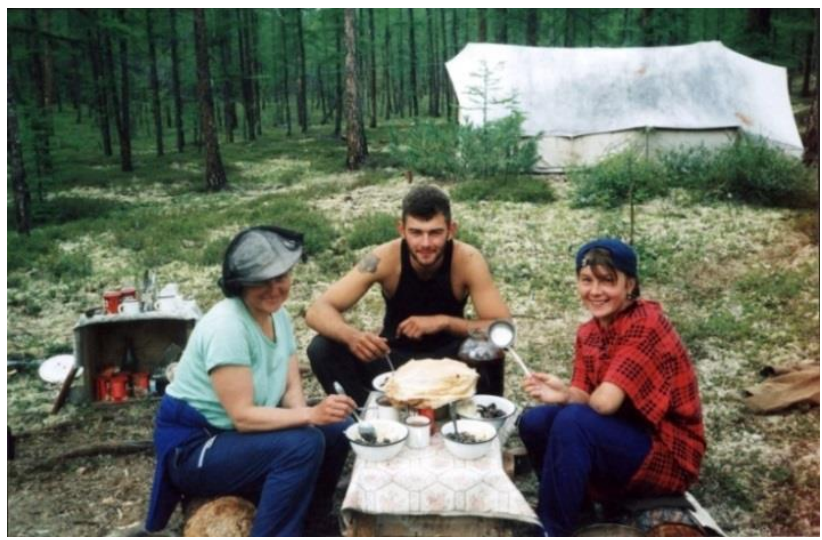

Слева направо: главный геолог Уакитской партии Минина О.Р., студентыл-практиканты - Чувашин А. (Зверобой) и Минина А..

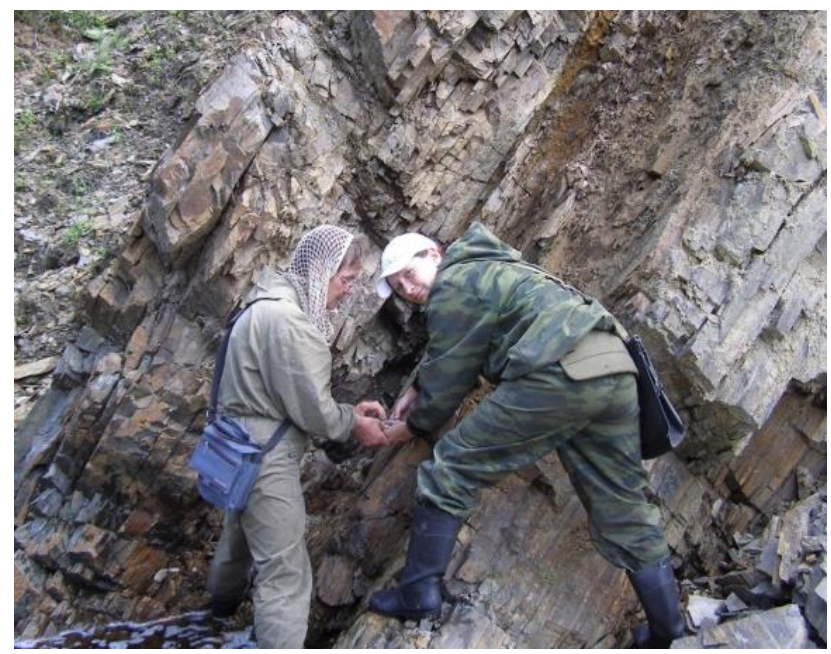

Слева направо: геолог Доронина Н.А, студентка Оксана. 


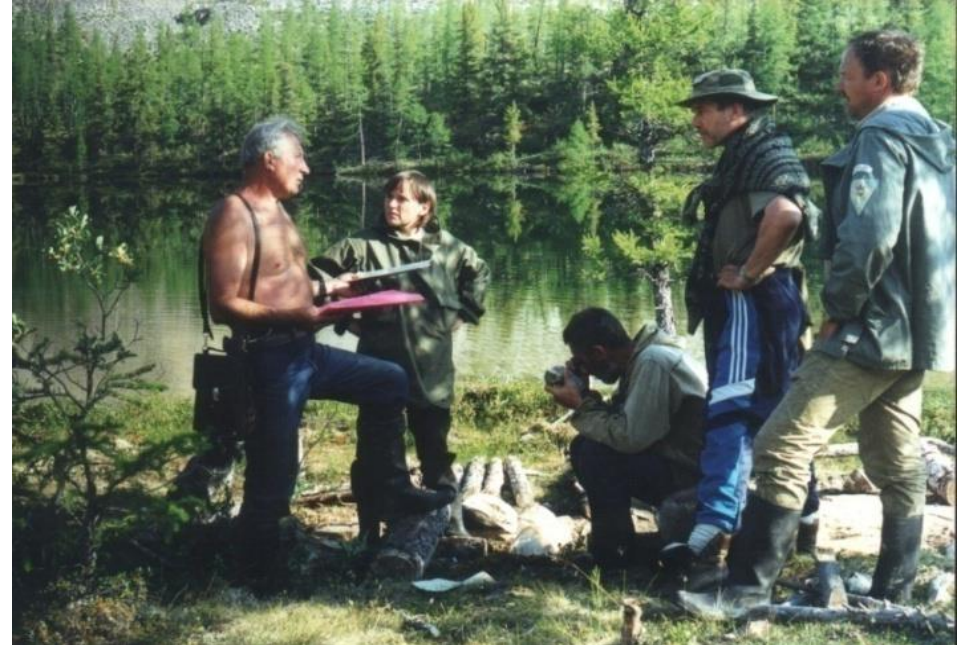

Геологические споры, Уакит, 2000 г. (слева направо) редактор Серийной легенды Г. Л. Митрофанов, главный геолог Уакитской партии О. Р. Минина, литолог А. В. Филимонов, декан B. М. Ненахов и преподаватель геолфака ВГУ А. В. Никитин. циалисты-палинологи Лидия Георгиевна Раскатова (руководитель лаборатории), Людмила Николаевна Неберикутина, Галина Макаровна Шишова, Раиса Сергеевна Холмовая, Тамара Федоровна Трегуб. Тогда и были получены первые данные о палеозойском возрасте ряда толщ, традиционно относившихся к докембрию. Мне посчастливилось быть знакомой с этим специалистами и учиться у них. В лабораторию я пришла еще студенткой в 1979 г. и со спорово-пыльцевым анализом меня познакомила Людмила Николаевна Неберикутина. Она терпеливо занималась со мной, научила меня «видеть» споры, что не каждому дано (это ее слова), объясняла важность палинологии при биостратиграфических исследованиях. За все эти годы Людмила Николаевна стала для меня не только мудрым наставником, но и близким человеком. Своими кандидатской и докторской диссертациями я обязана во многом именно ей. Палинологическое изучение стратифицированных образований региона продолжается уже более 30 лет. Опытные палинологи Неберикутина Людмила Николаевна и Трегуб Тамара Федоровна изучают палинофлоры Западного и Восточного Забайкалья, Монголии. Результаты их палинологических исследований являются основой для расчленения осадочных толщ, создания стратиграфических схем, позволяют геологам-забайкальцам решать многие вопросы, связанные с историей развития Монголо-Забайкальского региона.

Геологический факультет Воронежского университета и в настоящее время упорно готовит достойную кадровую смену уходящему геологическому поколению разведчиков недр. Геологи-воронежцы всегда отличались высоким уровнем профессиональной подготовки, умением решать сложные геологические вопросы, причем буквально с первых лет самостоятельной работы. Как-то один из уважаемых бурятских геологов сказал, что у воронежских молодых специалистов всегда сразу чувствуется хорошая «Школа». Эта «Школа» получена благодаря высокому профессиональному уровню профессорско-преподавательского состава Геологического факультета Воронежского госуниверситета, который уже более века сохраняет столь высокую «планку». И бурятские геологиворонежцы всех поколений с честью несут гордое ЗванИе ВЫПУСКНИКА ГЕОЛОГИЧЕСКОГО ФАКУЛЬТЕТА ВОРОНЕЖСКОГО УНИВЕРСИТЕТА.

Благодарности: Автор при работе над статьей пользовалась материалами, любезно предоставленными Бурятской организацией пенсионеров ветеранов-геологоразведчиков, Территориальными фондами. Особую признательность выражаю сотруднику Архива ТГФ Избродиной 3.В. и с.н.с ГИН СО РАН Л. Дамдиновой.

Конфликт интересов: Авторы декларируют отсутствие явных и потенциальных конфликтов интересов, связанных с публикацией настоящей статьи. 
Received: 12.02 .2020

Accepted: 20.02.2020

Published online: 25.03.2020

\title{
Graduates-geologists of the Voronezh State University in the Transbaikal
}

\author{
(C) 2020 O. R. Minina ${ }^{\bowtie}$ \\ Geological Institute of the Siberian Branch of the Russian Academy of Sciences, \\ 6A Sakhyanova st., Ulan-Ude 670000, Russian Federation
}

\begin{abstract}
The Republic of Buryatia is located in the southern part of Eastern Siberia, to the south and east of Lake Baikal. Buryatia is a federal subject of the Russian Federation and it is currently part of the Far Eastern Federal District. Buryatia is a leader among the majority of federal subjects of the Russian Federation based on the richness and diversity of resource potential. Over the past half century, more than 700 mineral deposits of various genesis have been identified in the Republic, out of which more than 600 were accounted by the State Register of Russia and the Territorial Register of the Republic of Buryatia. The entire territory of the region was studied by a standard medium scale geological survey. Graduates of the geological faculty of Voronezh State University made a great contribution to the study of the geological structure and the development of the mineral reserve base of the Republic of Buryatia.
\end{abstract}

Keywords: Voronezh State University, Buryatia, graduates, geologists.

Acknowledgments: The author used materials from the Buryat Organization of Pensioners of Veteran Geological Prospectors and Territorial Funds. The author is particularly grateful to employee of the TGF Archive Z. V. Izbrodina.

For citation: Minina O. R. Graduates-geologists of Voronezh State University in the Transbaikal. Vestnik Voronezhskogo gosudarstvennogo universiteta. Seriya: Geologiya = Proceedings of Voronezh State University. Series: Geology, 2020, No. 1, pp. 116-130. DOI: https://doi.org/10.17308/geology. $2020.1 / 2520$

Conflict of interests: The authors declare the absence of obvious and potential conflicts of interest related to the publication of this article.

Минина Ольга Романовна - д. г.-м. н., заведующая лабораторией геодинамики, Геологический институт Сибирского отделения РАН, Улан-Удэ, Российская Федерация; E-mail: minina@ginst.ru

Автор прочитал и одобрил окончательный вариант рукописи.
Olga. R. Minina - PhD, Dr. habil. in Geol.-Min., head of laboratory of geodynamics, Institute of Geology SB RAS, Ulan-Ude, Russian Federation;

E-mail:minina@ginst.ru

Author have read and approved the final manuscript.

The content is available under Creative Commons Attribution 4.0 License.

\footnotetext{
${ }^{凶}$ Olga R. Minina, E-mail: minina@ginst.ru
} 